() Мальцев Д.В., 2021

doi:10.37321/immunology.2021.3-04

УДК: 612.017.1:616-008]:577.164.17:577.121

\title{
ОЦІНКА МАРКЕРІВ ЗАПАЛЕННЯ ТА НЕЙРОНАЛЬНОГО ПОШКОДЖЕННЯ У ПАЦІЄНТІВ З РОЗЛАДАМИ СПЕКТРУ АУТИЗМУ, АСОЦІЙОВАНИМИ $З$ ГЕНЕТИЧНИМ ДЕФІЦИТОМ ФОЛАТНОГО ЦИКЛУ
}

\author{
МАЛЬЦЕВ Д.В. \\ Інститут експериментальної і клінічної медицини НМУ імені О.О. Богомольця
}

Обґрунтування. Розлади спектру аутизму (PAC) зустрічаються наразі щонайменше серед $1 \%$ дітей сучасної популяції, причому зберігається тенденція до зростання частоти цієї психіатричної патології серед дитячого населення [6]. Хоча запропоновано більше 100 генетичних причин розвитку фенотипу РАC у дітей, більшість із них є раритетними і суттєво не впливає ні на велику поширеність хвороби, ні на тенденцію до збільшення частоти цих розладів у популяції. Генетичний дефіцит фолатного циклу (ГДФЦ) - доволі часта патологія людського геному, яка може пояснити сучасні епідеміологічні особливості РАС. Доказова база асоціації ГДФЦ та РАС у дітей ґрунтується на результатах 5 мета-аналізів рандомізованих контрольованих клінічних досліджень, що проведені з 2013 по 2020 рік і охоплюють результати від 8 до 25 випробувань за участю від 1361 до більше, ніж 3000 дітей з РАС та від 6591 до 7257 здорових дітей $[13,17,20,21,22]$. Встановлено, що ГДФЦ призводить до розвитку в організмі ряду патологічних біохімічних змін [14, 25, 26], включаючи гіпергомоцистеїнемію [11], що зумовлюють розвиток оксидативного стресу [6, 8]. Результати мета-аналізу рандомізованих контрольованих клінічних досліджень Guo B.Q. зі спів. 2020 року, що охоплював 31 випробування за участю 3304 дітей, включаючи 1641 пацієнтів з РАС без уточнення генетичної природи хвороби, продемонстрували, що гіпергомоцистеїнемія тісно асоційована з РАС у дітей, будучи типовою ознакою цієї гетерогенної когорти пацієнтів в цілому (Hedges's $\mathrm{g}=0,56 ; 95 \% \mathrm{Cl}=0,36-0,76$, $\mathrm{P}<0,001)$ [11]. Оскільки гіпергомоцистеїнемія - специфічний біохімічний феномен саме для ГДФЦ, результати даного мета-аналізу вказують, що ГДФЦ з-поміж інших генетичних аномалій $є$ наразі провідним чинником генетичної предиспозиції до розвитку РАС у дітей. Докази щодо розвитку оксидативного стресу з надлишком прооксидантних і дефіцитом антиоксидантних молекул при РАС ґрунтуються на результатах двох мета-аналізів і систематичних оглядів рандомізованих контрольованих клінічних досліджень, що охоплюють 87 випробувань за участю 9109 пацієнтів [6, 8]. Саме патологічні зміни біохімічного профілю і пов>язаний з цим оксидативний стрес вважають причиною порушеного розвитку імунної системи у дітей з РАС, асоційованими з ГДФЦ [16, 19]. У таких пацієнтів формується особлива форма імунодефіциту [1], що зумовлює розвиток ряду імунозалежних ускладнень, зокрема енцефалопатії, яка, власне, і призводить до клінічної картини РАC [3], інфекційного синдрому з переважанням інтрацелюлярних опортуністичних і умовно патогенних мікробів [4, 18], імунозапального синдрому, включаючи персистуючий імуноопосередкований ентероколіт [10, 24], алергічного синдрому [12], автоімунного синдрому [5, 9] та підвищеної схильності до розвитку неоплазій [7]. Власне енцефалопатія при ГДФЦ, окрім прямого метаболічного механізму розвитку, опосередкованого, зокрема, нейротоксичним впливом гомоцистеїну [3], здебільшого зумовлена впливом імунозалежних механізмів - інфекційних чинників $[4,18]$, автоімунних реакцій до нейронів і мієліну півкуль великого мозку [5, 9], системного/інтрацеребрального запалення [15, 23].

Докази розвитку персистуючої системної запальної реакції у дітей з РАС ґрунтуються на результатах 2 мета-аналізів рандомізованих контрольованих клінічних досліджень. Зокрема, дані першого систематичного огляду і мета-аналізу рандомізованих контрольованих клінічних досліджень показують підвищення сироваткової концентрації прозапальних медіаторів інтерлейкіну-1бета (ІЛ-1бета) ( $p<0,001)$, інтерлейкіну-6 (ІЛ-6) $(p=0,03)$, інтерлейкіну-8 $(p=0,04)$, інтерферону-гамма (ІФН-гамма) $(p=0,02)$, еотаксину $(p=0,01)$ і моноцитарного хемотаксичного фактору $1(p<0,05)$ і зниження вмісту протизапального цитокіну трансформуючого фактору росту бета $1(p<0,001)$ у дітей з PAC $(n=743)$ порівняно зі здоровими пацієнтами $(n=592)$ [15]. Результати мета-аналізу рандомізованих контрольованих клінічних досліджень, підготовленого Saghazadeh A. зі спів., який охоплює 38 випробувань за участю 2487 дітей, показують вірогідне підвищення сироваткових концентрацій фактору некрозу пухлини альфа (ФНП-альфа), ІФН- 
гамма, ІЛ-1бета та ІЛ-6 у дітей з РАС порівняно зі здоровими особами [23].

Важливим $€$ подальше вивчення показників системного запалення у дітей з РАС для визначення найінформативніших біомаркерів оцінки інтенсивності запалення, які могли б бути корисними для клінічної практики. Потребує уточнення клінічна значущість феномену персистуючого системного запалення у дітей з РАС. Доцільним $€$ вивчення зв'язку між підвищенням сироваткової концентрації тих чи інших прозапальних медіаторів і показниками нейронального пошкодження, що надало б додаткові докази внеску системного запалення в розвиток енцефалопатії і дозволили б запропонувати до апробації нові медикаментозні методи нейропротекції у дітей з РАС, асоційованими з ГДФЦ.

Мета дослідження: вивчити сироваткові концентрації типових прозапальних медіаторів ФНП-альфа, ІЛ-6 та тумор-М2-піруваткінази (ТМ2ПК) у дітей з РАС, асоційованими з ГДФЦ, з уточненням їх зв'язку з сироватковими концентраціями маркерних молекул пошкодження нейронів ЦНС нейрон-специфічної енолази (HCE) та білка S-100 для розширення наукових уявлень щодо впливу системної запальної реакції на розвиток енцефалопатії при даній патології і відкриття нових точок прикладення дії нейропротекторного лікування.

\section{МАТЕРІАЛИ I МЕТОДИ}

Проаналізовано медичні дані 138 дітей віком від 3 до 8 років з ГДФЦ, у яких відзначалися РАС (97 хлопчиків і 41 дівчинка). Усі вони були пацієнтами спеціалізованої нейроімунологічної клініки Vivere (реєстраційне досьє від 22.12.2018 №10/2212-М). Отримання даних для дослідження та обробка матеріалу проводилася згідно договору № 150221 від 15.02.2021р., та висновку комісії біоетичної експертизи (протокол № 140 від 21.12.2020 р. НМУ імені О.О. Богомольця). Клінічний діагноз РАС був виставлений дитячими психіатрами за критеріями DSMIV-TR (Diagnostic and Statistical Manual of mental disorders) та ICD-10 (The International Statistical Classification of Diseases and Related Health Problems). Патогенні поліморфні варіанти генів фолатного циклу визначали методом ПЛР на підставі виявлення заміни нуклеотидів MTHFR C677T у моноформі (27 пацієнтів), а також - у поєднанні 3 іншими замінами нуклеотидів MTHFR A1298C, MTRR A66G i/або MTR A2756G (111 осіб). Ці особи склали досліджувану групу (ДГ). До контрольної групи (КГ) віднесли 51 дитину (37 хлопчиків та 14 дівчаток) аналогічного вікового розподілу, які не страждали на ГДФЦ.

У пацієнтів обох груп спостереження аналізували результати дослідження сироваткових концентрацій трьох типових прозапальних медіаторів, що характеризують інтенсивність системного запалення в організмі людини, зокрема - ФНП-альфа ( $\mathrm{N}$ до 8,1 пг/мл), ІЛ-6 ( $\mathrm{N}$ до 7 пг/мл) та ТМ2ПК (N до 20 ОД/мл). Паралельно в обох групах спостереження оцінювали дані з вимірювання концентрації в сироватці крові двох характерних показників нейронального пошкодження, а саме - HCE (N до 16,5 нг/мл) та білку S-100 ( $\mathrm{N}$ до 0,105 мкг/л). На момент проведення лабораторних досліджень пацієнти обох груп спостереження не приймали жодних ліків, які могли б вплинути на результати аналізів.

Статистичну обробку отриманого матеріалу проводили шляхом порівняльного і структурного аналізів. Для визначення вірогідності відмінностей між досліджуваними лабораторними показниками у групах спостереження використовували параметричний Т-критерій Ст'юдента з показником довірчої ймовірності р та непараметричний критерій - число знаків Z за Урбахом Ю.В. Вірогідними вважали відмінності при $p<0,05$ i $Z<Z 0,05$. Для вивчення асоціацій між показниками системного запалення та індикаторами пошкодження нейронів ЦНС застосовували показник відношення шансів (odds ratio, OR) та 95\% довірчий інтервал $(95 \%$ CI). 3 метою проведення статистичних розрахунків користувалися програмою Microsoft Excel.

Дане клінічне дослідження виконувалося як фрагмент науково-дослідної роботи на замовлення МО3 України (№ держреєстрації 0121U107940).

Результати дослідження та їх обговорення. Дані структурного аналізу результатів дослідження лабораторних показників системного запалення в групах спостереження демонструють, що найчастішим виявленим розладом було підвищення сироваткової концентрації прозапального медіатора ТМ2ПК, яке відзначалося у 119 із 138 пацієнтів ДГ (86\%) і тільки у 11 із 51 дітей КГ (22\% випадків). Сироваткова концентрація прозапального цитокіну ФНП-альфа була високою у 85 із 138 дітей ДГ (62\%) і тільки у 7 із 51 дітей КГ (14\% випадків). Концентрація у сироватці крові іншого прозапального цитокіну ІЛ-6 виявилася підвищеною у 43 із 138 дітей ДГ (31\%) і тільки у 3 із 51 дітей КГ (6\% випадків) (рис. 1).

Дані порівняльного аналізу вказують, що відзначалася вірогідна різниця за досліджуваними показниками системного запалення в групах спостереження за рахунок вірогідно більшої питомої ваги підвищених сироваткових концентрації всіх трьох досліджуваних лабораторних показників системного запалення серед дітей з РАС, асоційованих з ГДФЦ, порівняно зі здоровими дітьми контрольної групи ( $<<0,05$; $\mathrm{Z}<\mathrm{Z0}, 05)$. 
ІМУНОЛОГІЯ ТА АЛЕРГОЛОГІЯ: НАУКА І ПРАКТИКА. 3'2021

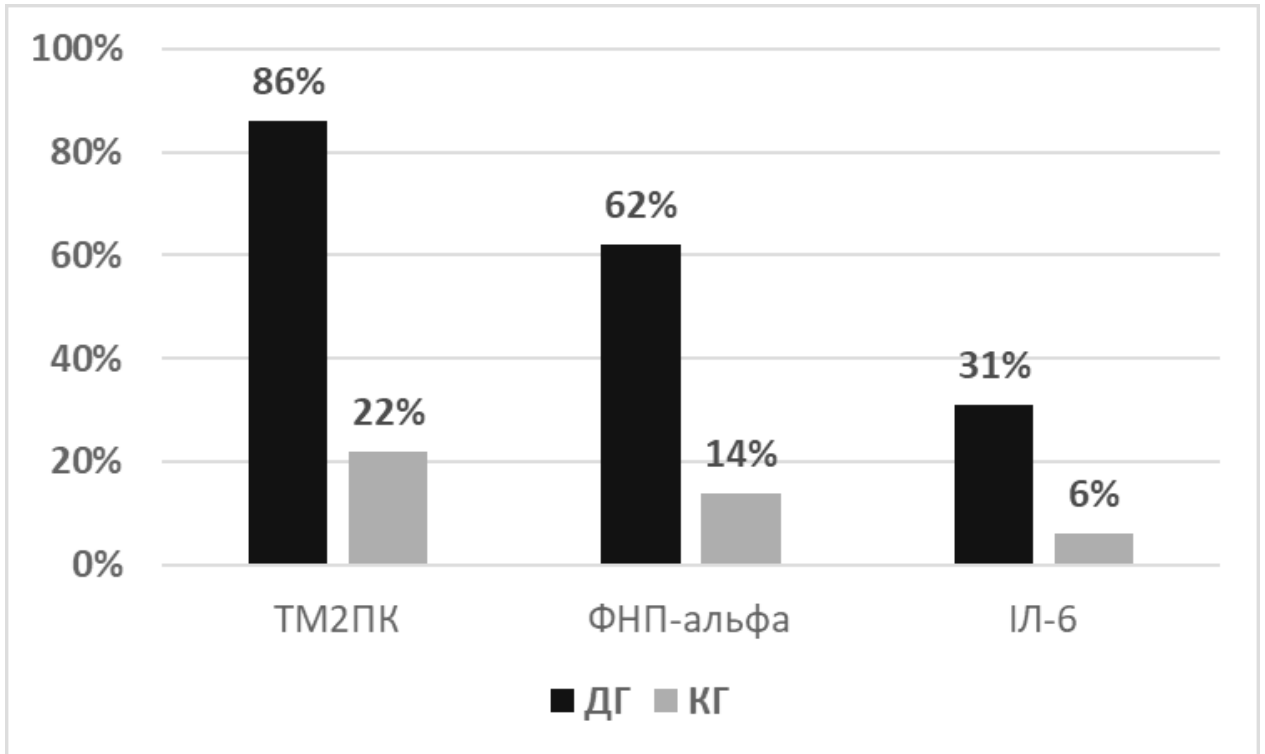

Рис. 1 Результати вивчення структури ДГ ( $=138)$ і КГ $(n=51)$ за випадками підвищених сироваткових концентрацій досліджуваних прозапальних медіаторів

ТМ2ПК виявилася найрепрезентативнішим біомаркером системного запалення в КГ, оскільки підвищення сироваткової концентрації цього прозапального медіатора відзначалося майже у всіх пацієнтів. Однак порівняно велика кількість псевдопозитивних результатів (22\% випадків серед здорових дітей) дещо знижує інформативність цього індикатору при оцінці інтенсивності системного запалення у дітей з РАС, асоційованими з ГДФЦ. Певно, в спірних випадках цей показник слід приймати до уваги тільки при додатковому підтвердженні результатами вивчення інших індикаторів запалення $з$ меншою кількістю псевдопозитивних результатів. Концентрація ФНПальфа була підвищено у більшості дітей КГ, однак кількість позитивних результатів була майже на третину меншою, ніж у ТМ2ПК. Мала кількість псевдопозитивних результатів (14\%) дозволяє вважати ФНП-альфа інформативним показником запальної реакції, який, однак, не характеризує групу в цілому через порівняно велику кількість негативних результатів (38\% випадків). Сироваткова концентрація ІЛ-6 була підвищеною тільки в третині випадків серед дітей КГ, що не дозволяє вважати цей біомаркер репрезентативним щодо всіх пацієнтів з РАС, асоційованими з ГДФЦ, для яких характерний розвиток персистуючого системного запалення в організмі. Однак найменша кількість псевдонегативних результатів цього показника дозволяє розглядати його найнадійнішим серед інших індикаторів, які вивчалися в даному дослідженні. Зокрема, сироваткові концентрації ФНП-альфа та ІЛ-6 можна використовувати для верифікації результатів вимірювання концентрації ТМ2ПК, для якої характерні псевдопозитивні результати у кожного п'ятого пацієнта.
Середня сироваткова концентрація ТМ2ПК в ДГ була високою і дорівнювала 63,1 33,74 ОД/ мл, вірогідно перевищуючи аналогічний показник у КГ $(23,2 \pm 0,91$ ОД/мл) ( $<<0,05 ; Z<Z 0,05)$ (рис. 2). Рівень середньої сироваткової концентрації ТМ2ПК втричі перевищував верхню межу референтних значень, що вказує на великий діапазон флуктуації результатів його вимірювання. Натомість середня концентрація ФНП-

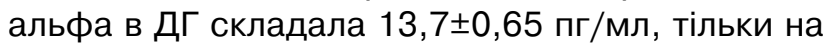
$60 \%$ перевищуючи верхню межу діапазону норми, демонструючи менший розмах флуктуації результатів вимірювання. Порівняння 3 аналогічними даними КГ (X = 5,3 0,38 пг/мл) вказує на вірогідне підвищення сироваткової концентрації ФНП-альфа у дітей з РАС, асоційованими з ГДФЦ, порівняно зі здоровими дітьми ( $p<0,05$; $Z<Z 0,05)$. Середня сироваткова концентрація

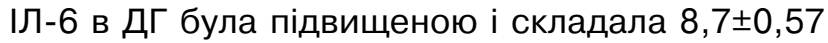
пг/мл, що тільки на 20\% вище верхнього рівня референтних значень, що вказувало на вузький діапазон коливання результатів вимірювання цього індикатору. Відзначалася вірогідна різниця за цим показником в ДГ і КГ $(X=3,6 \pm 0,27$ пг/мл) $(p<0,05 ; Z<Z 0,05)$ (рис. 3). Чим більша широта діапазону коливання результатів вимірювання показника, тим легше клініцисту оцінювати інтенсивність запалення і порівнювати результати досліджень у різних пацієнтів. Тому саме ТМ2ПК краще за ФНП-альфа та ІЛ-6 характеризувала інтенсивність запалення, за рахунок великого діапазону флуктуації результатів, повніше демонструючи градацію інтенсивності системної запальної реакції у різних пацієнтів.

Таким чином, середні величини сироваткових концентрацій всіх трьох досліджуваних по- 
казників були вірогідно підвищеними в Дг порівняно з КГ, що вказувало на наявність лабораторних ознак системного запалення у дітей з РАC, асоційованих з ГДФЦ, і відповідає результатам відповідних мета-аналізів рандомізованих клінічних досліджень [15, 23]. Однак відзначені суттєві відмінності як у питомій вазі випадків підвищеної сироваткової концентрації того чи іншого досліджуваного показника, так і в рівнях середніх сироваткових концентрацій і діапазоні коливання результатів вимірювань щодо кожного індикатору.

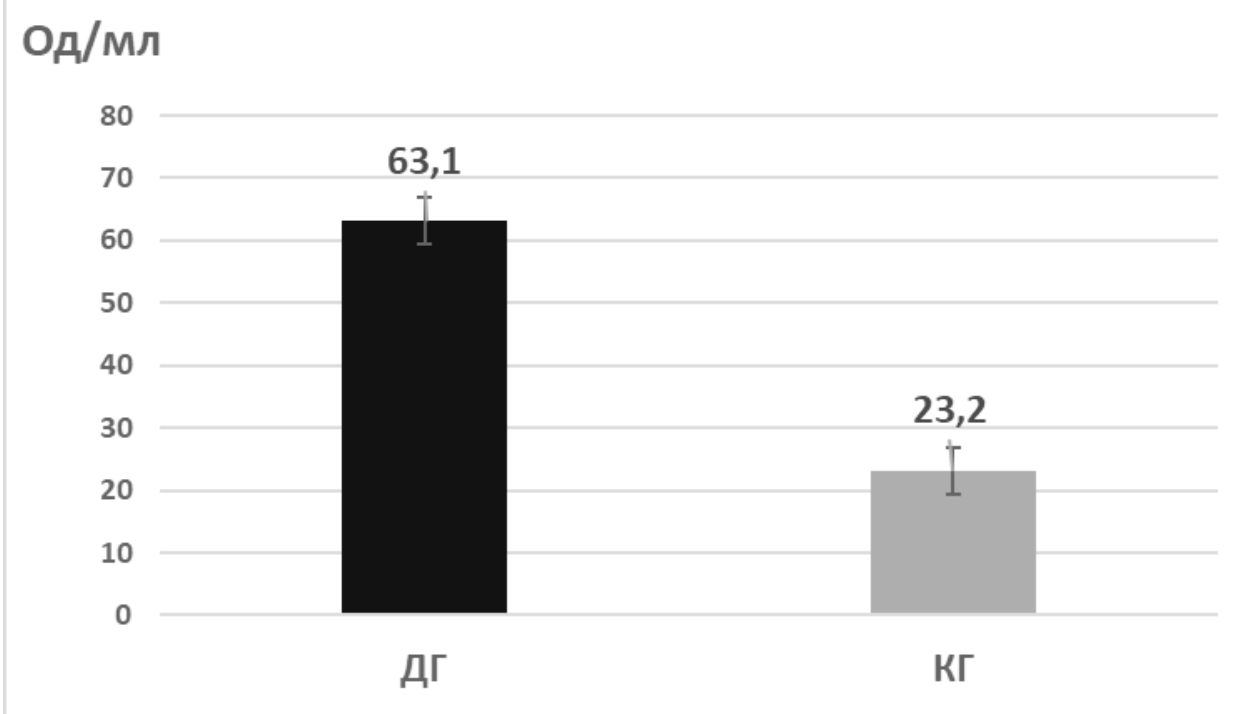

Рис. 2. Середі величини сироваткової концентрації ТМ2ПК в ДГ ( $n=138)$ і КГ (n= 51)

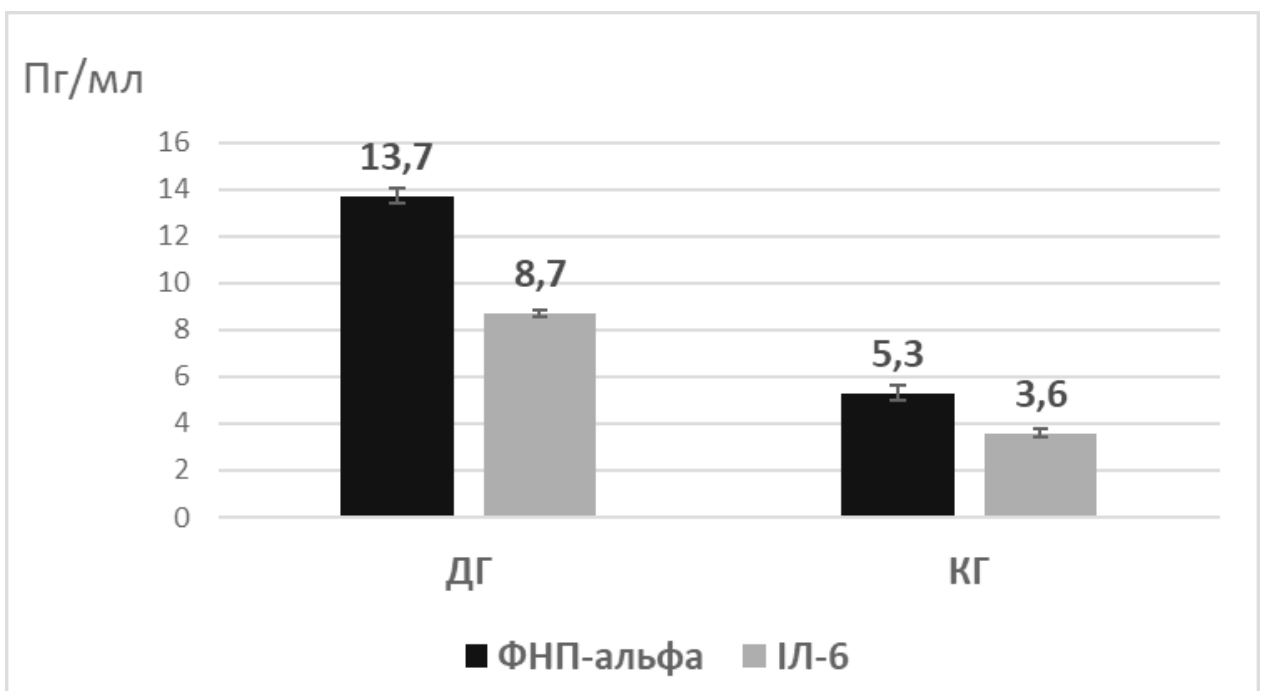

Рис. 3. Середі величини сироваткових концентрацій ФНП-альфа та ІЛ-6 в ДГ ( $\mathrm{n}=138)$ і КГ $(\mathrm{n}=51)$

ТМ2ПК виявилася найчутливішим та найлабільнішим лабораторним показником системного запалення 3-поміж інших досліджуваних індикаторів у дітей з РАС, асоційованими з ГДФЦ, який, однак, мала найменшу специфічність, даючи псевдопозитивні результати щонайменше у кожного п'ятого пацієнта. Натомість ІЛ-6 був найменш чутливим і лабільним індикатором системного запалення в ДГ, який, однак, характеризувався високою специфічністю, даючи псевдопозитивні результати тільки у кожного двадцятого пацієнта, тобто принаймні в 4 рази рідше, ніж ТМ2ПК. ФНП-альфа характеризувався середньою чутливістю і лабільністю з порівняно невеликою кількістю псевдопозитивних результатів, тому саме цей показник серед трьох досліджуваних лабораторних індикаторів можна вважати найбільш інформативним для оцінки інтенсивності запалення у дітей з РАС, асоційованими з ГДФЦ. Важливим є комплексний аналіз результатів вимірювання всіх трьох досліджуваних показників системного запалення, оскільки кожен із них має певні переваги і недоліки порівняно з іншими.

Принциповим є питання клінічної значущості системного запалення, що відзначається у дітей з РАС, асоційованими з ГДФЦ. Зокрема, необхідно уточнити внесок системного запа- 
лення в розвиток енцефалопатії у таких дітей віднайти найінформативніші біомаркери для оцінки запального механізму церебрального пошкодження. Для цього провели аналіз асоціацій досліджуваних показників системного запалення з сироватковими концентраціями індикаторів ураження нейронів ЦНС HCE і білку S-100 (табл.). Вибір останніх $є$ невипадковим, оскільки їх інформативність для оцінки виразності енцефалопатії у дітей з РАС продемонстрована у відповідних клінічних дослідженнях. Zheng Z. зі спів. провели мета-аналіз рандомізованих клінічних досліджень щодо вивчення інформативності використання сироваткової концентрації нейротропного кальцій-залежного білку S-100 у дітей з РАС. Було проаналізовано результати 10 випробувань, що охоплювали 822 учасника. Показано, що концентрація в сироватці крові білку S-100 вірогідна вище у дітей з РАC порівняно зі здоровими особами і може бути використана в якості біомаркеру нейронального пошкодження в таких випадках (standardized mean difference $(\mathrm{SMD})=0,97,95 \% \mathrm{Cl}=0,41-1,53 ; \mathrm{p}<$ 0,001) [27]. Відповідно до цього, Lv M.N. зі спів. провели спеціально сплановане контрольоване клінічне дослідження за участю 80 пацієнтів з РАС, продемонструвавши вірогідно підвищену концентрацію НСЕ в сироватці крові у дітей із зазначеним психічним розладом порівняно зі здоровими особами [14].

Результати вивчення асоціації (OR; 95\% Cl) досліджуваних показників системного запалення та індикаторів нейронального пошкодження серед пацієнтів ДГ $(n=138)$

\begin{tabular}{|c|c|c|c|}
\hline Показник & тм2пк & Фнп-альфа & Іл-6 \\
\hline НСЕ & 6,$667 ; 1,668-26,639$ & 11,$667 ; 2,064-65,945$ & 26,$667 ; 1,843-385,793$ \\
\hline Білок S-100 & 7,$570 ; 1,888-30,351$ & 10,$000 ; 1,784-56,060$ & 15,$200 ; 1,157-199,642$ \\
\hline
\end{tabular}

Як видно з даних табл., всі три досліджувані показники системного запалення асоційовані зі зростанням сироваткової концентрації лабораторних індикаторів нейронального пошкодження HCE і білку S-100, що вказує на зв'язок між системною запальною реакцією та розвитком енцефалопатії у дітей з РАС, асоційованими 3 ГДФЦ. Визначення підвищених сироваткових концентрацій досліджуваних показників системного запалення у результатах лабораторних обстежень пацієнта різко і вірогідно підвищує ризик ідентифікації високого вмісту в сироватці крові таких маркерів пошкодження нейронів ЦНС, як HCE і білок S-100, що може використовуватися в клінічній практиці при плануванні і організації параклінічних обстежень пацієнта.

Найтісніша асоціація виявлена щодо ІЛ-6 та маркерів пошкодження нейронів, однак клінічне застосування цього феномену може бути обмежено низькою чутливістю сироваткової концентрації ІЛ-6 як індикатору системної запальної реакції в окресленій групі пацієнтів. ТМ2ПК демонструвала найслабшу 3-поміж інших досліджуваних показників асоціацію з сироватковими концентраціями HCE і білку S-100, що можна пояснити порівняно великою кількістю псевдопозитивних результатів при вимірюванні цього лабораторного індикатору. ФНП-альфа займав середнє положення за тіснотою асоціації з показниками нейронального пошкодження порівняно з ТМ2ПК та ІЛ-6. В цілому справджувалося правило: чим специфічніший був лабораторний показник щодо оцінки інтенсивності системної запальної реакції у дітей з РАС, асоційованими з ГДФЦ, тим тіснішу асоціацію той демонстрував з досліджуваними показниками нейронального пошкодження і краще характеризував нейротоксичний вплив системного запалення на головний мозок пацієнтів.

Дані, виявлені в цьому дослідженні, не тільки розширюють сучасні уявлення щодо розвитку системного запалення і його впливу на формування енцефалопатії у дітей з РАС, асоційованими з ГДФЦ, але й відкривають шлях до апробації нових терапевтичних антизапальних стратегій нейропротекції шляхом таргетного нейтралізуючого впливу на прозапальні молекули. Успіх застосування інфліксимабу, препарату моноклональних антитіл до молекули ФНП-альфа, у дітей з РАC [2] має спонукати до рішучіших дій 3 планування та реалізації подальших спеціальних клінічних досліджень з вивчення ефективності і безпечності сучасних антизапальних лікувальних підходів у дітей з РАС, асоційованих з ГДФЦ.

\section{вИСновКИ}

У пацієнтів з РАС, асоційованими з ГДФЦ, відзначається підвищення сироваткових концентрацій таких прозапальних показників, як ТМ2ПК, ФНП-альфа та ІЛ-6, що вказує на стан системного запалення в організмі цих дітей. Якщо говорити про клінічну значущість досліджуваних індикаторів системного запалення, то останні суттєво відрізняються за чутливістю, лабільністю і специфічністю. ТМ2ПК є найчутливішим і найлабільнішим показником з порівняно 
великою кількістю псевдопозитивних результатів, в той час як ФНП-альфа займає проміжне положення, а ІЛ-6 характеризується найнижчою чутливістю і лабільністю, однак - найвищою специфічністю. Жоден з досліджуваних показників не можна вважати ідеальним для оцінки стану системного запалення у дітей з РАС, асоційованими з ГДФЦ, що передбачає необхідність комплексного аналізу даних. Всі досліджувані показники системного запалення асоційовані зі зростанням в сироватці крові індикаторів нейронального пошкодження НCE і білку S-100, що підтверджує усталені уявлення щодо ролі системного запалення в індукції енцефалопатії у дітей $з$ РАС, асоційованими з ГДФЦ, та відкриває шлях до апробації нових терапевтичних стратегій $з$ антизапальної нейропротекторної терапії.

\section{ЛITEPATУPA}

1. Мальцев Д.В. Оценка иммунного статуса у детей с расстройством аутистического спектра, ассоциированным с генетическим дефицитом фолатного цикла // Лікарська справа. - 2018. - №1-2. - С. 11-23.

2. Мальцев Д.В., Натрус. Л.В. Эффективность инфликсимаба при расстройствах спектра аутизма, ассоциированных с генетическим дефицитом фолатного цикла //Психиатрия, психотерапия и клиническая психология. 2020. - T. 11, № 3. - C. 583-594.

3. Bhatia P., Singh N. Homocysteine excess: delineating the possible mechanism of neurotoxicity and depression // Fundam. Clin. Pharmacol. - 2015. - Vol. 29(6). - P. 522-528.

4. Binstock T. Intra-monocyte pathogens delineate autism subgroups // Med. Hypotheses. - 2001. - Vol. 56(4). - P. 523-531.

5. Cabanlit M., Wills S., Goines P. et al. Brainspecific autoantibodies in the plasma of subjects with autistic spectrum disorder // Ann. N. Y. Acad. Sci. - 2007. - Vol. 107. - P. 92-103.

6. Chen L., Shi X.J., Liu H. et al. Oxidative stress marker aberrations in children with autism spectrum disorder: a systematic review and meta-analysis of 87 studies $(\mathrm{N}=9109) / /$ Transl. Psychiatry. - 2021. - Vol. 11(1). - P. 15.

7. Crawley J.N., Heyer W.D., LaSalle J.M. Autism and Cancer Share Risk Genes, Pathways, and Drug Targets // Trends. Genet. - 2016. - Vol. 32(3). - P. 139-146.

8. Frustaci A., Neri M., Cesario A. et al. Oxidative stress-related biomarkers in autism: systematic review and meta-analyses // Free Radic. Biol. Med. - 2012. - Vol. 52(10). - P. 21282141.
9. Frye R.E., Sequeira J.M., Quadros E.V. et al. Cerebral folate receptor autoantibodies in autism spectrum disorder // Mol. Psychiatry. 2013. - Vol. 18(3). - P. 369-381.

10. Furlano R.I., Anthony A., Day R. et al. Colonic CD8 and gamma delta T-cell infiltration with epithelial damage in children with autism // J. Pediatr. - 2001. - Vol. 138(3). - P. 366-372.

11. Guo B.Q., Li H.B., Ding S.B. et al. Blood homocysteine levels in children with autism spectrum disorder: An updated systematic review and meta-analysis // Psychiatry Res. - 2020. - Vol. 291. - P. 113283.

12. Li H., Liu H., Chen X. et al. Association of food hypersensitivity in children with the risk of autism spectrum disorder: a meta-analysis // Eur. J. Pediatr. - 2020. - Online ahead of print.

13. Li Y., Qiu S., Shi J. et al. Association between MTHFR C677T/A1298C and susceptibility to autism spectrum disorders: a meta-analysis // BMC Pediatr. 2020. - Vol. 20(1). - P. 449.

14. Lv M.N., Zhang H., Shu Y. et al. The neonatal levels of TSB, NSE and CK-BB in autism spectrum disorder from Southern China // Transl. Neurosci. - 2016. - Vol. 7(1). - P. 6-11.

15. Masi A., Quintana D.S., Glozier N. et al. Cytokine aberrations in autism spectrum disorder: a systematic review and meta-analysis // Mol. Psychiatry. - 2015. - Vol.20(4). - P. 440-446.

16. Mead J., Ashwood P. Evidence supporting an altered immune response in ASD // Immunol. Lett. - 2015. - Vol. 163(1). - P. 49-55.

17. Mohammad N.S., Shruti P.S., Bharathi V. et al. Clinical utility of folate pathway genetic polymorphisms in the diagnosis of autism spectrum disorders // Psychiatr. Genet. - 2016. Vol. 26(6). - P. 281-286.

18. Nicolson G.L., Gan R., Nicolson N.L., Haier J. Evidence for Mycoplasma ssp., Chlamydia pneunomiae, and human herpes virus- 6 coinfections in the blood of patients with autistic spectrum disorders // J. Neurosci Res. 2007. - Vol. 85(5). - P. 1143-1148.

19. Noriega D.B., Savelkoul H.F. Immune dysregulation in autism spectrum disorder // Eur. J. Pediatr. - 2014. - Vol. 173(1). - P. 33-43.

20. Pu D., Shen Y., Wu J. Association between MTHFR gene polymorphisms and the risk of autism spectrum disorders: a meta-analysis // Autism Res. - 2013. - Vol. 6(5). - P. 384-392.

21. Rai V. Association of methylenetetrahydrofolate reductase (MTHFR) gene C677T polymorphism with autism: evidence of genetic susceptibility // Metab. Brain Dis. - 2016. Vol. 31(4). - P. 727-735. 
22. Sadeghiyeh T., Dastgheib S.A., MirzaeeKhoramabadi K. et al. Association of MTHFR $677 \mathrm{C}>\mathrm{T}$ and 1298A $>\mathrm{C}$ polymorphisms with susceptibility to autism: A systematic review and meta-analysis // Asian J Psychiatr. 2019. - Vol. 46. - P. 54-61.

23. Saghazadeh A., Ataeinia B., Keynejad K. et al. A meta-analysis of pro-inflammatory cytokines in autism spectrum disorders: Effects of age, gender, and latitude // J. Psychiatr. Res. - 2019. - Vol. 115. - P. 90-102.

24. Torrente F., Ashwood P., Day R. et al. Small intestinal enteropathy with epithelial IgG and complement deposition in children with regressive autism // Mol. Psychiatry. - 2002. Vol. 7(4). - P. 375-382.

25. Wang Z., Ding R., Wang J. et al. The Association between Vitamin $D$ Status and Autism Spectrum Disorder (ASD): A Systematic Review and Meta-Analysis // Nutrients. 2020. - Vol. 13(1). - E86.

26. Yektaş Ç., Alpay M., Tufan A.E. et al. Comparison of serum B12, folate and homocysteine concentrations in children with autism spectrum disorder or attention deficit hyperactivity disorder and healthy controls // Neuropsychiatr. Dis. Treat. - 2019. - Vol. 15. - P. 2213-2219.

27. Zheng Z., Zheng P., Zou X. et al. Peripheral Blood S100B Levels in Autism Spectrum Disorder: A Systematic Review and MetaAnalysis // J. Autism. Dev. Disord. - 2020. Online ahead of print.

\section{PЕЗЮME \\ ОЦІНКА МАРКЕРІВ ЗАПАЛЕННЯ ТА НЕЙРОНАЛЬНОГО ПОШКОДЖЕННЯ У ПАЦІЄНТІВ З РОЗЛАДАМИ СПЕКТРУ АУТИЗМУ, АСОЦИЙОВАНИМИ З ГЕНЕТИЧНИМ ДЕФІЦИТОМ ФОЛАТНОГО цИкЛУ}

Мальцев Д.В.

Інститут експериментальної і клінічної медицини НМУ імені О.О. Богомольця

Обґрунтування. Доказова база асоціації генетичного дефіциту фолатного циклу (ГДФЦ) та розладів спектру аутизму (РАC) у дітей ґрунтується на результатах 5 мета-аналізів рандомізованих контрольованих клінічних досліджень. Системне запалення, яке виникає внаслідок ГДФЦ у дітей з РАС, розглядають як важливий механізм розвитку енцефалопатії. Потребує уточнення клінічна значущість феномену персистуючого системного запалення у дітей з РАС. Доцільним $€$ вивчення зв'язку між підвищенням сироваткової концентрації тих чи інших прозапальних медіаторів і показниками нейронального пошкодження в таких випадках.
Мета роботи: вивчити сироваткові концентрації типових прозапальних медіаторів фактору некрозу пухлини альфа (ФНП-альфа), інтерлейкіну ІЛ-6 (ІЛ-6) та тумор-М2-піруваткінази (ТМ2ПК) у дітей 3 РАС, асоційованими з ГДФЦ, з уточненням їх зв'язку з сироватковими концентраціями маркерних молекул пошкодження нейронів ЦНС нейрон-специфічної енолази (HCE) та білка S-100 для розширення уявлень щодо впливу системної запальної реакції на розвиток енцефалопатії при даній патології і відкриття нових точок прикладення дії нейропротекторного лікування.

Матеріали і методи. Досліджувану групу (ДГ) склали 138 дітей з діагнозом розладів спектру аутизмy (DSM-IV-TR та ICD-10), у яких відзначався генетичний дефіцит фолатного циклу (MTHFR C677T + MTHFR A1298C і/або MTR A2756G і/або MTRR A66G; ПлР). Контрольна група (КГ) включала 51 здорову дитину відповідного вікового і гендерного розподілу.

Досліджували сироваткові концентрації прозапальних медіаторів ТМ2ПК, ФНП-альфа, ІЛ-6 та показників нейронального пошкодження - HCE та білку S-100.

Результати дослідження та їх обговорення. Відзначалося підвищення сироваткових концентрацій ТМ2ПК у 119 із 138 пацієнтів ДГ (86\%) і тільки у 11 із 51 дітей КГ (22\%) (p<0,05; Z<Z0,05), ФНП-альфа - у 85 із 138 дітей ДГ (62\%) і тільки у 7 із 51 дітей КГ (14\%) (p<0,05; Z<Z0,05), ІЛ-6 - у 43 із 138 дітей ДГ (31\%) і тільки у 3 із 51 дітей КГ (6\% випадків) ( $<<0,05 ; Z<Z 0,05)$. Середні сироваткові концентрації ТМ2ПК в ДГ складала 63, $1 \pm 3,74$ ОД/мл порівняно з 23,2 $\pm 0,91$ ОД/мл в КГ (p<0,05; Z<Z0,05),

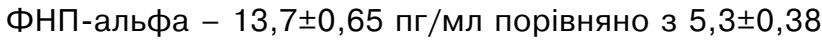

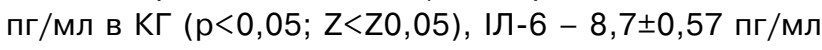

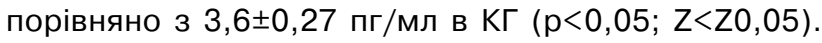
ТМ2ПК, ФНП-альфа та ІЛ-6 суттєво відрізнялися за чутливістю, лабільністю і специфічністю як маркери системного запалення у дітей з РАС, асоційованими з ГДФЦ.

Всі три досліджувані показники системного запалення були асоційовані зі зростанням сироваткової концентрації лабораторних індикаторів нейронального пошкодження ЦНС HCE і білку S-100, що вказує на зв язок між системною запальною реакцією та розвитком енцефалопатії у дітей з РАС, асоційованими з ГДФЦ.

Висновки. Отримані дані не тільки розширюють сучасні уявлення щодо розвитку системного запалення та його участі в формуванні енцефалопатії у дітей з РАС, асоційованими з ГДФЦ, однак і відкриває шлях для апробації сучасних антизапальних нейропротекторних лікувальних стратегій.

Ключові слова: нейрон-специфічна енолаза, білок S-100, тумор-М2-піруватикіназа, фактор некрозу пухлини альфа, інтерлейкін 6. 


\section{PЕЗЮME \\ ОЦЕНКА МАРКЕРОВ ВОСПАЛЕНИЯ И НЕЙРОНАЛЬНОГО ПОВРЕЖДЕНИЯ У ПАЦИЕНТОВ С РАССТРОЙСТВАМИ СПЕКТРА АУТИЗМА, АССОЦИИРОВАННЫМИ С ГЕНЕТИЧЕСКИМ ДЕФИЦИТОМ ФОЛАТНОГО ЦИКЛА}

Мальцев Д.В.

Институт экспериментальной и клинической медицины НМУ имени А.А. Богомольца

Обоснование. Доказательная база ассоциации генетического дефицита фолатного цикла (ГДФЦ) и расстройств спектра аутизма (РАC) у детей основывается на результатах 5 мета-анализов рандомизированных контролируемых клинических исследований. Системное воспаление, которое возникает в результате ГДФЦ у детей с РАС, рассматривают как важный механизм развития энцефалопатии. Требует уточнения клиническая значимость феномена персистирующего системного воспаления у детей с РАС. Целесообразным является изучение связи между повышением сывороточной концентрации тех или иных провоспалительных медиаторов и показателями нейронального повреждения.

Цель работы: изучить сывороточные концентрации типичных провоспалительных медиаторов фактора некроза опухоли альфа (ФНО-альфа), интерлейкина 6 (ИЛ-6) и тумор-М2-пируваткиназы (ТМ2ПК) у детей с РАС, ассоциированными с ГДФЦ, с уточнением их связи с сывороточными концентрациями маркерных молекул повреждения нейронов ЦНС нейрон-специфической енолазы (НСЭ) и белка S-100 для расширения представлений о влиянии системной воспалительной реакции на развитие энцефалопатии при данной патологии и открытия новых точек приложения действия нейропротекторного лечения.

Материалы и методы. Исследуемую группу (ИГ) составили 138 детей с диагнозом расстройство спектра аутизма (DSM-IV-TR и ICD-10), у которых отмечался генетический дефицит фолатного цикла (MTHFR C677T + MTHFR A1298C, и/или MTR A2756G, и/или MTRR A66G; ПЦР). Контрольная группа (КГ) включала 51 здорового ребенка соответствующего возрастного и гендерного распределения.

Изучали результаты измерения сывороточных концентраций провоспалительных медиаторов ТМ2ПК, ФНО-альфа и ИЛ-6 и показателей нейронального повреждения - НСЭ и белка S-100.

Результаты исследования и их обсуждение. Отмечалось повышение сывороточных концентраций ТМ2ПК у 119 из 138 пациентов ИГ (86\%) и только у 11 из 51 детей КГ (22\%) (p<0,05; Z<Z0,05), ФНО-альфа у 85 из 138 детей ИГ (62\%) и только у 7 из 51 детей КГ (14\%) (p<0,05; Z<Z0,05), ИЛ-6 - у 43 из 138 детей ИГ (31\%) и только у 3 из 51 детей КГ (6\% случаев) ( $p<0,05$; $\mathrm{Z}<\mathrm{ZO}, 05)$. Средняя сывороточная концентрация

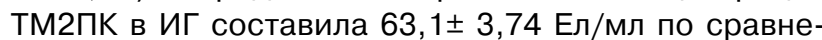
нию с 23,2 $\pm 0,91$ ЕД/мл в КГ ( $p<0,05 ; Z<Z 0,05)$, ФНО-

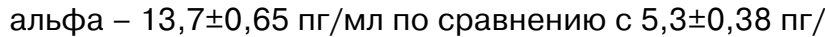

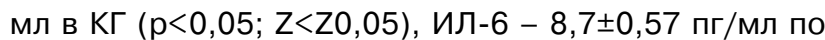
сравнению с 3,6 $\pm 0,27$ пг/мл в КГ (p<0,05; Z<Z0,05). ТМ2ПК, ФНО-альфа и ИЛ-6 существенно отличались по чувствительности, лабильности и специфичности как маркеры системного воспаления у детей с РАC, ассоциированными с ГДФЦ.

Все три исследуемые показателя системного воспаления были ассоциированы с ростом концентрации в сыворотке крови лабораторных индикаторов нейронального повреждения НСЭ и белка S-100, что указывает на связь между системной воспалительной реакцией и развитием энцефалопатии у детей с РАС, ассоциированными с ГДФЦ.

Выводы. Полученные данные не только расширяют современные представления о развитии системного воспаления и его участия в формировании энцефалопатии у детей с РАС, ассоциированными с ГДФЦ, но и открывают путь для апробации современных антивоспалительных нейропротекторных лечебных стратегий.

Ключевые слова: нейрон-специфическая енолаза, белок S-100, тумор-М2-пируватикиназа, фактор некроза опухоли альфа, интерлейкин 6.

\section{ABSTRACT \\ EVALUATION OF MARKERS OF INFLAMMATION AND NEURONAL DAMAGE IN PATIENTS WITH AUTISM SPECTRUM DISORDERS ASSOCIATED WITH GENETIC DEFICIENCY OF THE FOLATE CYCLE}

Maltsev $D$.

Institute of Experimental and Clinical Medicine at the $\mathrm{O}$ Bogomolets National Medical University

Backgrounds. The evidence base of the association of genetic folate cycle deficiency (GFCD) and autism spectrum disorders (ASD) in children is based on the results of 5 meta-analyzes of randomized controlled clinical trials. Systemic inflammation, which occurs as a result of GFCD in children with ASD, is considered an important mechanism for the development of encephalopathy. The clinical significance of the phenomenon of persistent systemic inflammation in children with ASD needs to be clarified. It is advisable to study the relationship between increased serum concentrations of certain pro-inflammatory mediators and indicators of neuronal damage in such cases.

The aim: to study the serum concentrations of typical proinflammatory mediators tumor necrosis factor alpha (TNF-alpha), interleukin IL-6 (IL-6) and tumor-M2-pyruvate kinase (TM2PK) in children with ASD associated with GFCD, with clarification of their with serum concentrations of so-called markers of neuronal damage CNS neuron-specific enolase (NSE) and S-100 protein to expand the understanding of the influence of systemic inflammatory response on the development of encephalopathy in this pathology and the discovery of new points of application of neuroprotective treatment.

Materials and methods. The study group (SG) consisted of 138 children diagnosed with autism spectrum disorders (DSM-IV-TR and ICD-10), who had a genetic deficiency of the folate cycle (MTHFR C677T + MTHFR A1298C and/or MTR A2756G and/or MTRR A66G). The control group (CG) included 51 healthy children of the appropriate age and gender distribution. 
Serum concentrations of pro-inflammatory mediators TM2PK, TNF-alpha, IL-6 and neuronal damage indicators NSE and S-100 protein were studied.

Research results and their discussion. There was an increase in serum concentrations of TM2PC in 119 of 138 patients with SG (86\%) and only in 11 of 51 children CG (22\%) ( $p<0.05 ; \mathrm{Z}<\mathrm{Z0.05})$, TNF-alpha - in 85 of 138 children SG (62\%) and only 7 of 51 children CG (14\%) ( $p<0.05 ; Z<Z 0.05)$, IL-6 - 43 of 138 children SG $(31 \%)$ and only 3 of 51 children of CG ( $6 \%$ of cases) $(p<0.05 ; Z<Z 0.05)$. The average serum concentrations of TM2PC in SG was $63.1 \pm 3.74 \mathrm{IU} / \mathrm{ml}$ compared with $23.2 \pm 0.91 \mathrm{IU} / \mathrm{ml}$ in $\mathrm{CG}(\mathrm{p}<0.05 ; \mathrm{Z}<\mathrm{Z0.05})$, TNF-alpha $13,7 \pm 0.65 \mathrm{pg} / \mathrm{ml}$ compared with $5.3 \pm 0.38 \mathrm{pg} / \mathrm{ml}$ in $\mathrm{CG}$ $(\mathrm{p}<0.05 ; \mathrm{Z}<\mathrm{ZO} 0.05), \mathrm{IL}-6-8.7 \pm 0.57 \mathrm{pg} / \mathrm{ml}$ compared with $3.6 \pm 0.27 \mathrm{pg} / \mathrm{ml}$ in $C G(p<0.05 ; Z<Z 0.05)$. TM2PK, TNF-alpha and IL-6 differed significantly in sensitivity, la- bility and specificity as markers of systemic inflammation in children with ASD associated with GFCD.

All three studied indicators of systemic inflammation were associated with an increase in serum concentrations of laboratory indicators of neuronal damage NSE and S-100 protein, indicating the link between systemic inflammatory response and the development of encephalopathy in children with ASD associated with GFCD.

Conclusions. The obtained data not only expand modern ideas about the development of systemic inflammation and its participation in the formation of encephalopathy in children with ASD associated with GFCD, but also open the way for testing modern anti-inflammatory neuroprotective treatment strategies.

Key words: neuron-specific enolase, S-100 protein, tumor-M2-pyruvate kinase, tumor necrosis factor alpha, interleukin 6 .

\section{АВТОРСЬКА ДОВІДКА}

\footnotetext{
- Мальцев Дмитро Валерійович Інститут експериментальної і клінічної медицини Національного медичного університету імені 0.0. Богомольця, зав. лабораторією імунології і молекулярної біології

Адреса: 01601, просп. Перемоги, 34, Київ, Україна

Тел.: (068)100-85-95

E-mail: dmaltsev@ukr.net
}

\author{
- Мальцев Дмитрий Валерьевич \\ Институт экспериментальной и клиничес- \\ кой медицины НМУ имени А.А. Богомоль- \\ ца, зав. лабораторией иммунологии и \\ молекулярной биологии \\ Адрес: 01601, просп. Победы, 34, \\ г. Киев, Украина \\ Тел.: (068) 100-85-95 \\ E-mail: dmaltsev@ukr.net
}

\author{
- Maltsev Dmytro \\ Experimental and Clinical Medicine Institute \\ at the 0.0. Bohomolets National Medical \\ University \\ Address: 34 Peremohy ave. \\ Kyiv 01601, Ukraine \\ Tel.: (068) 100-85-95 \\ E-mail: dmaltsev@ukr.net
}

